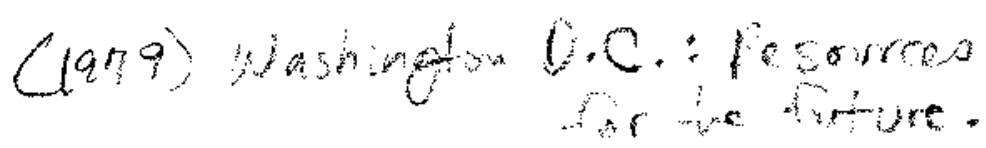

Chapter 5

PUBLIC CHOICE ANALYSIS OF INSTITUTIONAL CONSTRAINTS ON FIREWOOD PRODUCTION STRATEGIES IN THE WEST AFRICAN SAHEL

James T. Thomson

This essay presents a public choice policy analysis of firewood production possibilities in the West African Sahel, the arid southern fringe of the Sahara Desert.

Demand for firewood has outstripped supply in much of the contemporary Sahel. Arid areas and urban hinterlands now face the worst pinch, bt population growth will soon create scarcities in many regions where supplies remain temporarily adequate. Since firewood will amost certainly continue to be the staple cooking and heating fuel of most Sahelien

families, sustained severe shortages will sharply reduce many saheliens' living standards.

Author's Note: Research upon which this article is based was undertaken in Niger and Upper Volta during 1979, with funding provided by the International Relations Fellowship Program of the Rockefeller Foundation and by the Junior Faculty Leave Program of Lafayette College, Easton, Pennsylvania. I wish to acknowledge my appreciation for this support. I am also grateful to the governments of Niger and Upper Volta for authorizing the research. My greatest debt, however, is to all those Saheliens who willingly bore with countless questions about renewable 
The pertinent problem thus becomes identification in particular settings of best strategies to prevent serious firewood shortages. Using standard public choice assumptions about human nature, this analysis highlights technical, legal, political, and economic impediments to reforestation and then suggests several strategies to reduce or overcome them. Drawbacks as well as advantages of individualist, collective, and mixed approaches to Woodstock management are considered.

Arguments and analysis are presented in the following sequence:

(1) assumptions and an outline of seven problems to be considered; (2) a particularly fictionalized account of one individual's frustrating attempt at fuelwood production, which illustrates some of these problems in a Sahelien local context; (3) consideration in detail of each problem; and (4) conclusions.

\section{Assumptions and Problems}

The people whose behavior is here analyzed and who must implement any solutions are assumed to be self-interested, rational maximizers who make decisions under conditions of uncertain information (and therefore often satisfy rather than maximize). They do so within a basic legal framework which varies from place to place but establishes in any local context parameters of their decision-making processes. People are also assumed to be capable of learning over time as new information becomes available (Ostrom, 1974, pp. 50-52).

\section{Constraints on Firewood Production}

Assume that a Sahelien state wants to promote local participation in firewood production. Then assume home and market demand suffice, all else being equal, to encourage peasant production. Certain constraints may nevertheless hamper sustained yield management of the local Woodstock. Major problems are concerned with:

1. The availability of seeds or seedlings, or both, and whether there is nursery stock or natural regeneration, of appropriate species. In land-scarce and food-short areas, "appropriateness" will reflect species' compatibility with crops, effects on soil fertility, and valuable by-products.

2. Land tenure, tree tenure, and associated residential patterns which may blunt farmers' interest in wood production if they do not own land they farm; and affect the ease with which trees are protected, thus causing choices to be made between woodlot and on-field production schemes.

3. The feasibility of protecting trees from foraging livestock.

4. The feasibility of protecting trees from unauthorized cutting by humans.

5. The enforceability of property rights in land, which influence the risks entailed and the advisability of going into such a slow-maturing crop as trees.

6. The enforceability of property rights in trees; that is, how can damage be claimed when protection fails?

7. The collective action capabilities at the local level, given distribution of political (rule-making) authority there and in overriding regimes.

Each of these issues may affect an African peasant's calculations about whether tree farming can fit in with his and others' goats and crops, that is, how desirable is it to undertake agro-sylvopastoralism in any particular sahelien setting? In the following section I will highlight Some relevant constraints.

Hedging the Law - A Bad Example by Way of Elucidating Wood Broduction Broblems

Abdu Issa runs a peasant farm on ten arid acres of the West African Sahel. One recent dry season he decided to start a fuelwood plantation/ 
windbreak through the middle of his sandy field, reducing wind erosion by planting the break counter to prevailing east-west winds.

Abdu put in Commiphora africana, a small tree often used for live fencing because it can be started from cuttings of existing stock in the dry season without using irrigation. Trimmed hedges become dense and grow up without shading adjoining crops. Modest nutrient requirements further reduce the hedge's competition with crops. The trimmed branches burn nicely and, though slow growing, the wood is hard enough for saddlemaking. Finally, C. africana is not on the protected species list in Abdu's country. He could cut it without fear of being fined by a forester, as he might be were he to opt to plant Acacia albida or any of fourteen other species on the endangered list. Nor would he need permission, available for a fee (or a small bribe), each time he wanted to trim the hedge. ${ }^{1}$

As his field lies close to his village home, Abdu figured the hedge would make life easier for his wife who gathers all the household's firewood.

Unfortunately, other villagers at first took too little, then too much interest in the hedge. Livestock roam freely here after the harvest. Once fields were bare, goats browsed the C. africana leaves and tender twigs in the daily struggle to fill their stomachs, thereby stunting the

1 The forestry code in this country in fact vests ownership of planted trees in those who planted them. But peasants are often reluctant to formally establish title, because they are afraid of foresters, because by which title may be established is vague, cumbersome, and of uncertain efficacy. In the absence of firm title, many forestry guards see an illegal opportunity to increase fines or bribe income .... and take it. little trees. Many villagers saw animals chewing on the hedge, but no one shooed them away: after all, local rules allow animals to rove freely during the dry season.

Local interest picked up, however, when the hedge put out burnable branches. Village women, too busy to comb surrounding fields for fuel, lopped off many for firewood. They all knew Abdu had planted the hedge but rationalized their actions by claiming the right as local residents to cut any unprotected species. Since hedges are by national law unregulated common property unless title has been established to specific trees. Those who did not cut Abdu's hedge never told him the names of those who did for fear of being labeled troublemakers.

Abdu's wife complained; and when he caught a woman "trimming" his hedge, he became angry enough to call a case against her before the cantor chief. Since he lived in the same town, time and court costs were minima Had Abdu lived ten miles from the canton seat in a village with no local moot, such court action would have been much more expensive in time and money .

Abdu presented his complaint in court. In reply the woman's husband publicly ridiculed him for being so petty as to haul an honest housewife to court over something so minor as a piece of wood. Moreover, he asserted, there really was no law preventing local people from trimming unprotected trees.

The canton chief, as judge, tried to decide after hearing the parties The case perplexed him: what did Abdu expect? The woman had taken wood all right, but it was worth practically nothing. Did he want two cents' worth of compensation? Embarrassed, Abdu said he did not care about 

that piece of wood, but he did want an end to unauthorized trimming of
his hedge. He asked for the equivalent of a two dollar fine. The chief declined. He had no legal authority to impose such a fine. Nor could he legislate new rules, even were they to apply solely within his canton. only his administrative superiors at the national level could make such decisions; at most he could merely conciliate the parties.

True, he might have let Abdu pronounce a Quranic oath to prohibit further hedge trimming without permission. But the penalties violators would face (leprosy, poverty, etc.) were too draconian for the value involved. Moreover, he knew his superiors would rebuke him if he consented to the oath. It really offered no solution to Abdu's problem.

The chief's admonitions finally convinced the husband his wife should give Abdu fifty cents in damages. She did; and after all the fuss, Abdu had to accept. For his troubles, he made himself a laughing stock of village gossips. Damages did not even cover court costs, to say nothing of his loss of face. Worse still, the amount would not deter future trimmers, the more so because everyone knew Abdu could not afford, in personal terms, to call another such case. Nor were others likely to do so, after this debacle.

Later somebody cut two good trees out of the windbreak. Abdu ignored the incident (though he could have used the wood), but the hole channeled strong air currents through the trees and severely eroded topsoil on both sides of the opening.

Fuelwood windbreaks have not become popular items in Abdu's village. Implications of this example for firewood production using other unprotected species are only too clear. On the other hand, to raise protected species for fuelwood would require the regional forester's written consent. Otherwise a standard permit would be needed to authorize cutting or even trimming above the three meter level.

This account suggests some of the social, legal, political, and technical constraints which may affect firewood policy and production schemes. Systematic examination of these and other obstacles to sustained yield management is now in order.

Constraints on Fuelwood Production

\section{Appropriate Tree Seeds or Seedlings}

To pervert a proverb, great oaks from little oaks grow $\ldots$... only. Seeds, seedlings, or saplings, from natural regeneration, direct seeding, or transplanted private or government nursery stock constitute the starting point of reforestation. Without them, it will not happen. They must be adapted to the job at hand, that is, reproduction must be technically and economically feasible, survival rates adequate in rainfed (or irrigated) plantings, and wood must be adequate as fuel. All else being equal, where demand is strong, faster growing species will be preferred. But other things are not equal. Species vary. Some produce good construction as well as firewood, or valuable by-products such as foods, medicines, gum, tannin, and fibers.

Nonconsumptive uses served by various species also vary markedly, and these may sharply influence a farmer's decision to grow one rather than another, or to grow trees at all. In land rich areas, crop competitive characteristics - space, light nutrients, and water requirements may be immaterial. But in infertile, land scarce areas villagers will 
be extremely sensitive to these aspects: fuelwood for cooking is a basic necessity only if there is food to cook. Thus, undeniable advantages are offered by species which fertilize crops through nitrogen fixation, reduce wind or water erosion, or act as nutrient pumps in bringing soil chemicals leached below the reach of crop roots to the surface again as do leaf mulch or manure (Poulsen, 1979a, p. 4, and 1979b, pp. 9-10). These onsite uses as well as growth characteristics will influence farmers' decisions to go into fuelwood or stick exclusively to crops.

If disseminated to farmers, improved varieties could tip the balance in favor of more wood production. Greater cash income from tree by-products and replacement of market by homegrown items might well compensate for less cropland. In this regard, much remains to be done in appropriate species research, development, and dissemination.

\section{Land Tenure, Tree Tenure, and Residential Patterns}

Land tenure. Land tenure can be succinctly defined as "those legal and contractual or customary arrangements whereby people in farming gain access to productive opportunities on the land" (Dorner, 1972, p. 17). Land tenure systems allocate productive opportunities. Those who firmly control land they farm can plan accordingly. But the tenant who expects his, landlord to evict or shift him to another plot after several years to prevent him from establishing title by prescription is not able to plan improvements with the same security. He may be perfectly aware that terracing, live fencing, or windbreaks eventually improve land and yet be certain that he will gain nothing thereby. Thus he may rationally opt for short-term investments in greater fertility. The use of manure or chemical fertilizer promises a return to investment at the next harvest, assuming he gets a reasonable share of the crop produced. Although such attempts to maintain soil fertility are probably inadequate in the long run, given undiminished wind or sheet erosion, the farmer who expects to move on will find them preferable to longer term, more fundamental improvements.

This logic applies with equal force to wood production schemes, since trees take at least four or five years to reach usable size. The potential fuelwood farmer whose view of the long term is cluttered with land tenure related risk factors cannot be faulted for hesitating to plant trees.

Tree tenure. Sahelien tree tenure terms often add another risk, thus inhibiting investments in fuelwood production. Land ownership and tree ownership do not always concede. In pre-colonial times he who plant a tree usually owned it. If he also owned the land under the tree, eithei might be sold without parting with the other. Trees growing wild in the bush by contrast often counted as "free goods" (or "bads," since they had to be cleared before the land could be cultivated).

It is probably that few rural Saheliens were initially disturbed by deforestation. Accustomed for centuries to slash-and-burn agriculture, they judged Woodstock levels by the availability of free bush land. ${ }^{2-}$ So long as forested lands remained for colonization, a frontier mentality prevailed. When the farmland and surrounding bush failed, migration or colonization commonly offered the easiest way out. Under such circum-

$2_{\text {Political boundaries drawn along ethnic or state lines clearly put }}$ some "available" lands off limits to aliens of the political communities involved. Such humanly imposed land shortages induced active conservatic practices in many areas (Ware, 1977, pp. 174-175). 
stances it made little sense to actively manage renewable resources. Renewable resources. Positive conservation measures to permit continuous use - windbreaks, sheet erosion control terraces and dikes, and so forth - demand sustained effort. They require more labor input than does clearing forested, fertile lands which can be fallowed when worn out while the farmer opens new fields elsewhere. Given sufficient land, passive conservation - fallowing fields well before they were totally exhausted adequately restored soil fertility and trees to the landscape, and the Saheliens knew this.

The colonial conquest brought a European style forest service and forestry regulations to most Sahelien areas by the 1930s. Modifications in tree tenure followed. Colonial officials, fearing deforestation, imposed forestry codes. These generally tried to freeze demand rather than promoting sustained yield management. Particularly in the French colonies codes restricted use of valuable species by establishing a protected species list and creating extensive forest reserves, without regard to customary African land and tree tenure rights (Raeder-Roitzsch, 1974). Upholding these regulations against popular resistance required suppressive police action, ever since a hallmark of Sahelien forestry. With foresters spending the greater part of their time chasing illegal cutters, opportunities for a cooperative approach to forestry were few indeed.

In many Sahelien states today deadwood and unprotected live species remain effectively unregulated common property. In supply tight situations of the sort becoming increasingly common in the sahel, this arrangement, often underwritten through local level misinterpretation of national forestry codes, discourages wood production. Where wood is available for the taking, wood ownership is established by appropriation, not by inve ment in planting, nurturing, and protection. Despite an urgent need fc reforestation, working rules of tree tenure in such cases render the activity virtually pointless from the perspective of individual conser Significantly, deadwood is becoming increasingly privatized in the evoJ common law of many African locales (for example, zinder Department, Nip and Yatenga Department, Upper Volta). This development reflects peasar dissatisfaction with forestry code rules as they are locally (and often incorrectly) interpreted. Research to determine villagers' perception? this situation should be a priority item in programs focusing on incent and deterrents to increasing fuelwood supplies.

Do shrinking firewood supplies make conservationists of peasants? If so, policy implications are far-reaching. Popular readiness to innc to experiment, and to do added work necessary to use new techniques sue cessfully may sharply reduce efforts needed to "sensitize" people. Pea who want to reforest because they foresee shortages should make a will! audience for forestry extension workers. Conversely, premature efforts to make active conservationists of villagers not yet convinced by perso observation of a resource crunch may merely waste everyone's time and money. Scattered fragmentary evidence suggests this is the case (Thorns 1979a, 1979b), but more research on the question is indispensable. In the meantime, a caveat is in order.

Pro-conservation attitudes by no means lead automatically to conservation activity. Intervening variables shape farmers' final estimat of feasibility of sustained yield management, whatever their desire for same. Three of these - availability of appropriate stock, effective 1 
and tree tenure rules - have just been examined. The remaining variables will be analyzed in the sections that follow.

Residential patters: closely settled versus dispersed. Some Sahelien peasants live in villages at the center of the community's fields. Others live in dispersed family units, each on its own field. If trees have to be protected - as seems likely - from grazing livestock and illegal trimming, dispersed settlement cuts surveillance costs for scatter-sited trees (windbreaks, live hedges, and trees interplanted with crops). Closesettled communities, with many more eyes and ears, can better patrol village woodlots located close to population centers. But such sites are often hard to come by: the richest fields constantly fertilized by compound sweepings, manure, and nightsoil lie in the first circle of land around the village (Raynaut, 1978).

Assume that only protected seedlings survive. Thus raising them in sites beyond range of costless surveillance implies either hiring a guard, enduring unauthorized depredations, or giving up. Because most locations in dispersed-settlement communities can always be seen by someone, such localities may enjoy a tactical advantage in wood production . over closely settled villages.

\section{Trees Versus Livestock}

Many knowledgeable observers maintain that sahelien reforestation is feasible only if trees receive adequate protection from browsing livestock, particularly goats, while others, such as Poulsen (1979c, pp. 6-8) argue the contrary. The issue is thus problematic; research should seek data to help decide when and where what species must be fenced to prosper. Given cross-Sahelien variations in grazing pressure and tree species auto-defense mechanisms (thornless, with thorns, and so forth), few sweeping generalizations about fencing are likely to be valid.

Major interdependences in traditional sylvo-agro-pastoral systems Symbiotic relationships between highly productive herding, farming, and tree-growing activities unquestionably exist (compare, for example, Funel, 1979; Nicolas, 1962; Souleymane, 1978; Swift, 1976; and Thomson, 1977). Trees, crops, and livestock in properly balanced relationships enrich and protect each other to the great benefit of the entire community. To maintain this system of mixed farming under a tree canopy at peak productivity interrelationships must be managed in mutually reinforcing ways. When this fails to take place, a desert may well result.

Controlling grazing pressure. If livestock can destroy natural regeneration of trees, reforestation depends on controlling livestock. In most Sahelien countries animals forage during the rainy season only under guard, but after the harvest livestock often roam at will. This cuts feeding costs, and investments in herding, enclosures, and fodder stocking are avoided.

Treating dry-season fields as common property lays the groundwork for an eventual. tragedy of the commons because it encourages overstocking. Each additional animal means more profit for the owner. But when the carrying capacity of a pasture is exceeded, each additional animal marginally reduces the food supply for every other animal. Hunger drives them all from the lush to the rough grasses and eventually to saplings, thus curtailing natural regeneration of the Woodstock. This is the classic tragedy of the commons, in which a once valuable renewable natural resource is reduced to dust or hardpan laterite by uncontrolled overgrazing (Hardin, 1968, and 1977). 
Two kinds of solutions exist to prevent overgrazing: privatization, which encourages each owner to take account of the full costs of overstocking his own land; or political controls, which keep grazing at or under carrying capacity. Both involve problems.

Short of privatization or grazing controls, fuelwood resources can be protected from livestock by regulating livestock movements or somehow protecting trees, whatever happens to pastures.

Herding requires pasturage, herders, and returns to investment to support the latter. Full-time migrant herders, who regularly move through the Sahel, for the example, the Fulbe and Twareg, are harder to control in terms of protecting the Woodstock from abusive cutting of woody browse than are sedentary herders who have a greater incentive to respect local regulations concerning exploitation of tree forage. For herders, keeping hungry animals from gardens and woodlots is easier than protecting scattered natural regeneration. Local goats, however, often are not herded: their limited value frequently does not justify the labor input.

Fencing is difficult because it is expensive, and traditional fencing materials - thorns, mats, and live hedges - may be scarce, either because it is protected by forestry code provisions (Thomson, 1977, pp. 6465; and Felker, 1978, pp. 118-119) or because population pressure has largely eliminated free bushlands. Enclosing larger areas reduces per unit cost, as some ethnic groups who maintain consolidated forms of land tenure have found (Nicolas, 1962; Souleymane, 1978; Thomson, 1977, pp. 261-264). Typically, however, this cannot be achieved when fields are small and scattered.

Stabling requires substantial labor inputs to collect fodder. Generally this is feasible only during the growing season, when grasses and foliage are plentiful near at hand. Tethering on pastures is again onl feasible when forage is plentiful, that is, when trees need no particul protection from livestock.

Where lack of appropriate sites precludes informal policing (above pp. 160, 161), seedling survival may depend upon active guarding. Loca funds (rates or voluntary contributions), money from overriding governm or international aid donors may permit hiring guards. Or, guard duty might be shared on a rotating basis within the village, assuming that effective local political institutions exist that can resolve problems associated with enforcing equitable participation in guard service.

Woodlots can be fenced given sufficient tradiational materials or units large enough to reduce wire fencing costs to acceptable levels, $p$ unit area. Reusing materials on other sites once trees have outgrown stock pressure will further reduce costs.

Scatter-site, in-field wood production may also be possible using browse-resistant species, or on a fenced basis, only if tree growers ax committed to protecting saplings and if they have legal access to enoug thorns from mature trees.

\section{Trees Versus People}

Doubts may exist about when, where, and how much foraging animals threaten wood production. But people unquestionably cut innumerable trees while harvesting fuelwood and other forest products. Whether the Woodstock as a renewable resource will be run down depends on instituté al incentives to balance supply and demand. As suggested, Sahelien tre may be private or common property, or a mix of the two. Theoretically, if trees are private property a wood shortage should stimulate individi 
investment in supply. Evidence from rural Niger and Upper Volta suggests this in fact happens. Indeed, forest service heads in Niger, Upper volta, and Mali are all currently interested in exploring this option along with collective approaches to reforestation.

By contrast, where trees are common property, wood will be harvested on a first come, first served basis (Thomson, 1977). This reduces incentives to produce, since the tree planter has no guarantee he will reap the benefit of his investment. To overcome this dissociation between investment in supply and reward inherent in all common property systems, special management capabilities must be developed. Some political community must control use and promote supply. Conceptually this is always possible; practically it is often difficult and costly - often, but not always.

\section{Trees as private property; protecting and producing to guarantee}

supply. Where trees are private property, tree owners either protect them or bear losses occasioned by theft. Two consequences flow from privatization: first, a "do to others as you would have them do to you" ethic is implicit, that is, don't steal wood if you don't want yours stolen. Second, tree owners and their dependents function as an informal local polic force. Community members thus help enforce tree tenure rules instead of leaving the job entirely to foresters. Perfect policing will not result. Some, preferring to avoid "meddling," will not report observed wood thefts to owners. But the incentive to do so is there: to protect one's own trees, one protects others' and hopes for reciprocity.

Privatization of trees also motivates individuals to produce trees for their own use. Where all trees are privately owned, he who does not provide for his future wood needs by growing now will later pay the going price for lumber and firewood. Because trees cannot be harvested on a first come, first served basis, the option to avoid investment in wood production no longer eixsts. Privatization brings home directly to the individual consequences of nonconservation, and so encourages planting and protecting future firewood supplies. While maturing, trees protect the environment.

Unregulated common property trees: consumption without production. The first come, first served rule governing exploitation of unregulated common property woodstocks promotes consumption but not production. Demand can exceed supply without automatically pressuring individuals to act in their enlightened self-interest by investing now in supplies to meet future needs and thus avoid total deforestation and environmental degradation.

The Sahelien peasants are often admonished to become aware of environmental degradation. By implication, ignorance or plain stupidity underlie peasants' current failure to take better care of the land and trees that support them. But it is highly unlikely that peasants fail to see the ecological breakdowns occurring around them. They may be aware and concerned, yet simultaneously immobilized by inappropriate rules.

What pushes an individual to ensure regeneration of an unregulated common property Woodstock threatened by excessive demand? Very little, in fact. The peasant who values trees on his field as windbreaks, forage sources, soil fertility regenerators, and the like will at most try to get his firewood eslewhere. If free bush exists nearby he will use that. But once bush goes, the desire for trees on his own field goads him to harvest those on his neighbors' fields to meet his own construction and 
firewood needs (Thomson, 1979b). Given excessive demand, the unregulated common property system leads to a "cut anywhere but home" ethic of forest exploitation. Instead of encouraging each landowner to invest in future supply, this ethic leads peasants to cut their losses by not investing in regeneration of common property Woodstock which somebody else will most likely consume. Instead,-people spend more time, energy, and money meeting daily needs from the everdwindling supply.

Spontaneous privatization of the woodstock. Assume that the Woodstock is formally unregulated: that is, any tree is legally fair game for anybody. Given resource scarcity, will privatization replace the first come, first served rule? ' Economic theory argues that the commons will be parceled into private units when it is both technically feasible to enforce property rights and economically advantageous to do so (Demsetz, 1967). Field data from a rural region of Upper Volta not patrolled by the national Environmental Service support the prediction. Parallel developments -- privatization of formerly common property crop residues (peanut vines, millet stalks, and the like) - in parts of Niger and Upper Volta, where destruction of bush has made livestock forage a scarce commodity, likewise support the prediction. This change lays one kind of groundwork for greater individual investment in wood supply. But other alternatives exist.

\section{Common proṕerty woodstock: formally regulated, effectively unreg-}

ulated. Assume that a woodstock is formally but not effectively regulated because of inadequate enforcement. Even though demand exceeds supply, incentives here still discourage better wood supply management through informal privatization. Everybody is in the same boat: all have to cut protected species illegally to satisfy urgent needs for wood. It is therefore difficult for anyone to protect his "own" trees by preventing others' cutting on his own land. ${ }^{3}$ Even worse, nobody can morally afford to assist foresters in protecting trees except where such "collaboration" is the only way to avoid unjust punishment for others' illegal cutting on one's own land.

This leaves the forest service with total responsibility for defendin the woodstock. Even assuming that foresters manage adequate policing with minimal peasant support, individual investments in regenerating the woodstock still will not occur. This conclusion follows from the continuing lack of direct connection between investment in new supply and expected reward, so long as the permit system effectively authorizes regulated cutting of protected species anywhere: tree planters still have no assurance they will harvest wood they grow.

\section{Reducing disincentives to invest in supply of common property wood}

stock. Disincentives to producing common property trees can be reduced by subdividing common property woodstocks into exclusive units allocated to specific user communities (which might be larger than, equal to, or smaller than village jurisdictions). Formalizing local control should encourage village investment in policing and increasing the woodstock, by explicitly allocating management responsibility to village residents. This strategy seems especially attractive where some fields are already

3 Given a formal permit system an individual could in principle acquir* one and then legally cut trees on his own land. But since foresters are thin on the ground, it is expensive in time and energy, at which point on must pay for the permit; and since they are thin on the ground it is usual ly possible to get away with illegal cutting. When this becomes everybody" least-bost solution, unregulated deforestation proceeds apace. 
treeless: it would reduce potential hardship some would otherwise suffer through privatization of trees currently maldistributed on village lands and should ease the transition to sustained yield management, by calming fears of those community members less well endowed with wood.

Village governments or quarter committees could regulate access. Local management units would be empowered to exclude nonresidents. ${ }^{4}$ By reducing information costs and facilitating the consensus required to maintain a local regulation system, such units might well cut policing and investment costs involved in building collective supply.

Adequate collective management decisions depend on accurate knowledge about who is doing what with the Woodstock. Wood must presumably be distributed under some locally acceptable formula which would equitably apportion supply and hardships associated with short supply. Details of distribution formulas appear to be an intimately local matter, defined by each local unit's consensus about what is right and proper. Two general conditions hold, however. First, such formulas must be enforceable to be effective. If those who run short are permitted to raid the collective Woodstock, the now inappropriate first come, first served rule will replace group management.

Second, a formula will only work if it is seen by villagers to achieve equity. Inequitable arrangements will be violated by aggrieved peasants

4 Where scattered quarter or village landholdings interpenetrate each other, interesting boundary problems can be expected. If they are sufciclenty intractable and collective management is considered a must, existing villages or quarter boundaries might offer a solution. district would regulate wood on a group of contiguous fields no matter where field owners resided or were registered for census and tax purposes. The approach is not without problems; however, they will not be explosed. here. pressed for fuel. Accurate information gathered in ways which local peop consider reliable can avoid this. Considerable room for local experiment exists here, but the smaller the user group and the greater their daily interaction the lower information costs will be (Olson, 1965). it may be possible to control use only of guarded woodlots: monitoring wood gather ng from on-field trees simply may be too expensive. If so, privatization of trees not in woodlots may be the only workable way to manage them on a sustained yield basis.

Consensus on distribution formulas and investment in new wood suppli will be easier where the quarter or village is accustomed to taking collective decisions, if the same process and persons can handle Woodstock management. Otherwise organizational difficulties must be surmounted before local collective management will be feasible. This may be both expensive and time-consuming. Given a consensus, users have some incentive to help with policing as a means of protecting their own shares. But the incentive is weakened because losses are spread over the entire group rather than being borne only by the one who sees illegal harvester. To overcome this handicap, consensus will have to be very solid.

Local collective management for sustained yield assumes sustains! investments in new supply. Planting trees and protecting natural regeneration require labor, perhaps money. ${ }^{\mathbf{5}}$ Management units thus require authority to impose user charges, labor service or taxes on group members

$\mathbf{S}_{\text {Acquiring access to woodlot sites poses fascinating problems. Loca }}$ tion of sites, terms of cession (sale? loan? rent? conditions of reversio to owner?), possible effects on distribution of product must all be regimes should offer a dispute resolution process only to settle intract- 
In many parts of the Sahel, such authority does not now exist, at least for purposes of collectively producing trees.

User fees might provide a way to sensitize users to the social impact of their individual demands on the Woodstock. They could promote conservation by adding a price to the time and energy invested in harvesting fuelwood. They could also generate funds to pay for additional fuelwood in the form of woodlots or by protecting natural regneration (fences, guards' or herders' remuneration). Again, adequate information and effective enforcement would condition feasibility. If total reliance on user charges would strain budgets of the pooerst persons it might be advisable to adopt either graduated fees (that is, to tax heavier users disproportionately more) or a mixed system, coupling fixed-ration distribution of the indespensable minimum amount of firewood with user charges for any additional amounts. Again, what will work depends on local institutions.

\section{Enforcement of Property Rights in Land}

This section treats the critical problem of rule enforcement. It builds on our earlier discussion of protection problems, particularly arguments about informal policing mechanisms and local collective action organization. Analysis of land tenure enforcement problems here will lay the groundwork for briefer comments in the next section about enforcement of collective or individual property rights in trees.

Enforcement: the indispensable minimum. Laws are man made artifacts designed to organize human conduct for certain ends. Effective laws, by restricting the choices open to individuals, raise odds that desired actions will occur.
Laws, however, are not self-enforcing. Formal laws only become effective when individuals and officials uphold them in cases of dispute $O$ violation. Without enforcement, laws remain mere formal orderings, pape rules, without capacity to shape realities of human conduct.

Commons's (1959, pp. 65-142) concept of working rules of going concerns provides a useful framework for analyzing enforcement issues. For Commons, any institution can be viewed as a going concern. Members' con duct is patterned by working rules - effective laws, which reflect officials' decisions of whether to enforce formal rules. Any set of workii rules creates opportunities, in the form of rights and liberties which encourage certain actions, and deterrents, duties and exposures, which discourage other activities (Ostrom, 1976).

Rights and liberties, however, are only desirable, duties and expos ures only onerous if they are enforced when challenged. Whether officia command the necessary power is problematic. Assuming they do, whether they will use it to uphold formal laws depends on whether their decision are subject to review by superior officials (and if so, how those offici, exercise their powers). And, if their decisions are not subject to revi. that is, if they have the last word, whether they consider a particular law should be upheld in light of their own analysis of the situation. Where an official has the last word, or determining power, danger always exists that the indispensable capacity to enforce laws by legally imposir "bads" on individuals and so coercing them to act in desired ways may be abused to promote the official's interests at the expense of at least some members of the going concern.

Where abuses are possible one can be sure officials and other membe of the concern will find ways to manipulate the legal process to their 
mutual advantage. In the sahel as elsewhere land tenure laws often become prime objects of manipulation as uncontrolled officials seek to promote their own interests in greater income, control over more land and power over people. Information about working rules, and the enforcement process that underlies them, is thus indispensable to achieving an accurate understanding of why people act as they do.

Legal costs. Legal costs include time and energy necessary to litigate, official and personal costs of coming into court, lawyers' fees. and illegal payments to court personnel.

Configurations of working rules are frequently much influenced by costs of legal action. All else being equal, the lower these are the more vigorous one can expect litigants to be in protesting rule violations and perceived unjust rulings. How officials' exercise their powers will thus face greater scrutiny, and as a result abuses will diminish.

Village moots to resolve disputes and maintain local rules probably offer the most efficient, low-cost solution to enforcement problems. Village moots by no means guarantee a just legal process. Yet appeals are usually possible to courts of higher jurisdiction. This provides a partial check on local court-holders and makes rule manipulation less attractive in their eyes if superiors consistently correct abuses. However, appeals, though necessary as a control measure, can threaten integrity of the local legal process if used too frequently. They may then make rule enforcement impossible at the village level (Thomson, 1977).

\section{Enforcement of Property Rights in Trees}

The question this section addresses may be simply stated; where excessive demand threatens the Woodstock, are trees valued enough by somebody so that rules promoting sustained-yield management can be upheld by forcement when necessary? This can be followed immediately by anoth question; What are the costs and, therefore, the likelihood of enfo

Increasing land shortages in most contemporary Sahelien communi and the critical importance of land as a basic factor of production Sahelien peasant families' farming economy ensures that most will vi ly litigate, even in the face of high legal costs, when their land c are challenged. Trees are another matter. Where supply exceeds dem peasants will not likely complain about cutting. Who cares? There enough left for everybody. Even when the balance changes, it may be time before people perceive the loss of a tree as a loss they suffer Sooner or later, however, the lack of wood will bring the point home Once people become aware of the loss, fundamental questions of tree and enforcement processes become pertinent. Who owns what? What kii policing deter violators? When formal rights are violated, what kin. of recourse are available and at what costs?

Policing: a first-order solution. Policing is an indispensabl towards management. It demonstrates somebody's direct concern with and puts potential violators on notice that they are illegally infrii collective or individual interests in the Woodstock.

State control and policing of the woodstock to the exclusion of local involvement in management is a major weakness of many contempoi Sahelien reforestation schemes. It dissociates policing and harvest interests: foresters police alone, and everybody else harvests on tI sly. Financing now available to Sahelien forestry agencies is insuf! to permit massive staff increases. Therefore, exclusive state polic 
as a control system seems doomed to severely suboptimal performance, and sustained-yield Woodstock management by such means is unlikely.

Local policing, where trees are collectively owned by local units or held by individuals, appears to offer a useful alternative. However, it must resolve the enforcement problem or witness a return to the working rule governing unregulated common property Woodstock exploitation: "cut anywhere but at home."

Local enforcement: calculations. Incentives to demand enforcement of tree tenure rules will be heightened if clear remedies exist when illegal cutting occurs. Restoration in kind or cash of wood value taken seems essential to indemnify community or individual owners. If user fees are enforced ( propriate fee for wood taken. Additional damage payments also seem advisable, both as a further deterrent and to compensate owners for loss of nonconsumptive uses they suffer when live trees are felled.

Note that combined sanctions must be adequate to deter but not so draconian as to hinder their application. Only the local sense of equity can set appropriate standards. Local autonomy in this respect is a necessary element in effective local management, as is the authority to modify penalty structures in light of changing definitions of equity.

As with land tenure enforcement, judicial costs to the litigant will affect his willingness to prosecute violators of tree tenure rules for restitution and punitive damages. Judicial costs - time to get to court and have the case heard, legal or illegal court costs, lawyers' fees - all represent outlays which somebody has to support. Unless legal costs are expected to be less than the value of the wood taken, wood owners are unlikely to bother with litigation. Again, through their proximity, availability, and informality, village moots will tend to cut costs, which is a great point in their favor. Individual owners may thei have enough incentive to defend their part of the Woodstock and so contri bute to overall management.

Collective ownership, because it spreads any loss sustained over all group members, probably means the management unit will have to designate an enforcer to represent the community in proceedings against violators. He should not be expected to shoulder the task on a voluntary basis: seJ sacrifice for community good is fine, but expecting one person to bear the entire burden of providing community benefit - maintenance of woodstock management rules - is asking a bit much.

\section{Issues of Collective Action}

For sustained-yield woodstock management to occur, supply and demand levels have to be balanced. Certain control measures noted above are indispensable to achievement of this goal. Even privatization involves local collective action in fixing and upholding tree tenure rules; otherwise enforcement costs will likely dissuade peasants from investing in wood production. Collective approaches to wood production, harvesting and distribution require correspondingly more elaborate local government capabilities.

Many villages in contemporary Francophone Sahelien areas lack legal authority necessary to sustain local management activities. Governments or external donors funding woodlot programs often "solve" the problems of collective organization that are associated with running such woodstock management projects by simply assuming that villages will handle them. Indeed, some villages can. Residual traditions of collective 
action, maintained by social pressure, permit them to impose necessary constraints. But many others cannot; traditions have eroded, informal collective action capability has greatly weakened or expired, rules governing use cannot be upheld locally over the long run; and without collective discipline, costs of management are simply prohibitive. Programs fail for lack of attention to critical issues of local government organization.

Note also that erosion of traditional forms (and their replacement by informal modern alternatives in some instances, for example, religious communities, voluntary associations, and the like) is extremely variable across, but also within, ethnic groups. Organizational capacity is a village-specific (or quarter-specific) phenomenon. Dramatic differences manifest themselves within villages and among quarters as well as among communities of the same ethnic group located in close proximity.

While project designers may ignore such problems, peasants cannot afford to do so. Nigerien Hausa community action is difficult: while some are farting with effort, others get new shirts." As many Hausa see it, those who voluntarily contribute money or effort for the public good (whatever the specific good) will find others "free-riding" on their sacrifices. Without enforcement free-riders will not bear their fair share of costs of producing goods. Hinging development efforts on willingness of people to get together for the community good will work well only where the village or groups within it are effective going concerns capable of organizing requisite efforts through a working system of rules. But where there exists no going concern - or one whose membership is limited to a small subset of the community population - the costs of getting together may be prohibitive, and people may have to opt for getting separated even though they know such a strategy may leave them worse off in the long run.

Projects should be designed to take account of this local complexity, by drawing on villages' organization strengths where possible and respecting others' limits by not arbitrarily imposing collective forms on those which now lack such capacity. Designs should build in local options to choose reforestation strategies from a range of possibilities. For certain kinds of reforestation programs it will be necessary in some locales to invest time and energy in reconstituting or creating local autonomous government capability.

Collective action costs. One can identify two kinds of costs as sociated with collective action: (1) costs of taking collective decision? for example, acquiring land for woodlots or imposing user fees; and (2) costs flowing from decisions taken, for example, land loss sustained by group members whose fields may be expropriated for community woodlots or user fees which people may be required to pay. (Vor a more formal treatment of these concepts - "opportunity" and "deprivation" costs -- see Ostrom, 1968, and literature therein cited.)

These costs vary with degrees of effective local autonomy and organization in any particular community. Where local structures can achieve consensus and uphold decisions with or without official authorization to enforce rules, the time and effort required to establish a Woodstock management structure may be relatively low。 But in consequence some people may bear substantial costs. They may lose land, or have to buy wood, or invest in new supplies when they would prefer to do other things with their time or money. 
On the other hand, where local government is weak, consensus may be extremely difficult to achieve and decisions impossible to impose. In consequence, people may escape immediate costs associated with decisions they do not like. It is probable, however, that failure to manage woodstock for sustained yield will lead ultimately to desertification in the Sahel, the costs of which are probably enormous.

If to manage their Woodstock local communities require authorization from higher government levels, for example, district, county, state, or national jurisdictions, in general one can expect costs of getting authorization will rise as the authorizing level becomes more remote. As jurisdictions increase in size, problems they deal with typically become more numerous. Since officials only have as much time as anyone else they typically cannot deal with all problems presented, but only with those they consider most important. A village petitioning for permission to manage its own Woodstock (in the absence of special enabling legislation) is likely to face great difficulty acquiring the requisite authority. Thus one can expect villages to be uninterested in formulating and present? ing such petitions. The problem will be dealt with, if at all, in a topdown manner by officials who view it as serious enough to merit their attention.

\section{Conclusions}

This analysis of firewood production problems in the West African Sahel has addressed tehcnical and institutional problems which may impede Woodstock management once dwindling wood supplies commit locàl residents to active conservation practices (Thomson, 1980a)" Clear possibilities exist in the region for greater tree production and sustained-yield
Woodstock management, but realizing these will depend on the awareness

of and ability to overcome problems discussed.

Technical advances - more appropriate species, production techniques, and so forth - remain critical: peasants already hard-pressed to survive will shun species and projects they know to be unproductive or threatening to short-term crop production possibilities.

Land and tree tenure rules, and political organization capabilities sharply influence the kind of Woodstock management strategy that is appropriate for any particular user community, as do judicial process and woodstock protection possibilities. Some villages or village quarters can master both individual and collective approaches to wood production.

Others, lacking appropriate local instituions, are restricted to individual enterprises. Probabilities that either will succeed can be heightened by legal changes, particularly in Sahelien national forestry codes. Reforms should give villagers greater incentives to participate in Woodstock management by authorizing local communities to make and enforce management rules necessary and relevant in light of local conditions. Reforestation project designs should likewise address these critical issues as the most efficient way of promoting effective reforestation and environmental management in sahelien states. 
References

Commons, John R. 1959. Legal Foundations of Capitalism (Madison, University of Wisconsin Press).

Demsetz, Harold. 1967. "Towards a Theory of Property Rights," American Economic Review, vol. 72 (May), pp. 347-359.

Dorner, Peter. 1972. Land Reform and Economic Development (Baltimore,

Felker, Peter. 1978. State of the Art: Acacia albida as a Complementary Permanent Intercrop with Annual Crops (Riverside, Calif., Department Riverside, for USAID, Grant No. AID/afr-C-1361).

Funel, J.M. 1979. "Espace physique et développement rural en Afrlque sudano-sahelienne: quelques variations sur ce theme," in $\mathrm{Ph}$. Couty et a., eds., Mas.trise de 1'espace, a raire et développemnt. en Afrique loque de Ouagadougou (4-8 decembre 1978) (Paris, Editions de l'office de la Recherche Scientifique et Technique Outre-Mer) pp. 229-238.

Hardin, Garrett. 1968. "The Tragedy of the Commons, " Science, vol. 162, pp. $1243-1248$.

-. 1977. "Ethical Implications of Carrying Capacity," in Garrett Hardin and John Baden, eds. Managing the Commons (San Francisco, Calif., W.H. Freeman) pp. $1 \frac{1}{2-123}$.

Nicholas, Guy. 1962. "Un village bouzou du Niger: étude d'un terroir, Cahiers d'outre-mer, vol. 40, no. 58, pp. 138-165. Olson, Mancur. 1965. The Loficic of Collective Action: Public Goods and
the Theory of Groups (Cambridge, Mass., Harvard University Press).

Ostrom, Elinor. 1968. "Some Postulated Effects of Learning on Constitutional Behavior," Public Choice, vol. 5, pp. 87-104. Ostrom, Vincent. 1974 . The Intellectual Crisis in American Public Ad-
ministration, rev. ed. UUniversity, Ala., University of Alabama

- 1976. "John R. Commons' Foundation for Policy Analysis, " Journal of Economic Issues, vol. 10, pp. 839-857.

Poulsen, Gunnar. 1979a. "Woodlots in the Sahel - Is That the Solution?" Sylva Africana, no. 4, pp. $3-4$ 1979b. "Agroforestry before the Word, "Sylva Africana no. 4

1979c. "Is Fencing of Plantations Necessary in the Sahel?" Syl Africana no. 4, pp. 608 .

Raeder-Roitzsch, J.E. 1974. "Institutional Forestry Problems in the Sahelian Region". (New York, United Nations, Secretariat, Special Sahelian Office [ST/SSo/32]).

Raynaut, Claude. 1978. "Rapport de synthese" (Bordeaux, France, Univc site de Bordeaux II [Analysis of environmental problems in Maradi Department, Niger, undertaken by Universite de Bordeaux II]).

Souleymane, Diarra. 1978. "Les Stratégies spatiales des éleveurs-cult vateurs peul du Niger central agricole," on Ph. Couty et al., eds. Maltrise de l'espace agraire et développement en Afrigue tropicale Logique paysanne et rationalite* technique, Actes du colloque de Ouagadougou (4-8 decembre 1978) (Paris, Editions de 1'Off
Recherche Scientifique et Technique Outre-Mer) pp. 87-81.

Swift, Jeremy. 1976. "La Désertification et l'homme" (Contribution lc de la Consultation CILSS/UNSO/FAO sur le rôle de la forêt dans un programme de réhabilitation du Sahel, Dakar, Senegal, April 26-May 1976)

Thomson, James 1. 1975. "Law, Legal Process and Development at the Lc Level in Hausa-Speaking Niger: A Trouble Case Analysis of Rural Institutional Inertia, (Ph.D. dissertation, Department of Politic Science, Indiana University, Bloomington, Indiana).

1977. "Ecological Deterioration: Local-Level Rule-Making and Enforcement Problems in Niger," in Michael H. Glantz, ed., Desert cation: Environmental Degradation in and around Arid Lands (Boulc Colo., Westview Press) pp. 57-79

979a. Interviews with Inuwa District (pseudonym) villagers di, field research, Inuwa District, Mirriah Arrondissement, Niger, Feb ruary-May 1979.

1979b. Interview with the Black Drummer, Kwari (pseudonum), nuwa District (pseydonym), Mirriah Arrondissement, Niger, April 1979.

1980a. "Rapport préliminaire de fin de mission; Les Programmer 1980a. "Rapport preliminaire de fin de mission; foréts, des psturages et des bas-fond sahéliens: les influences sur la mise oeuvre des structures locales au Niger et an Haute-Volta" (Eastons Pa., January 25, 1980) 
1980b. "Preliminary Evaluation: OXFAM Microcatchment Project, Ouahlgouya, Upper Volta" (Unpublished report, Ouahigouya, Upper Volta, March 15, 1980).

Ware, Helen. 1977. "Desertification and Population: Sub-Saharan Africa," antz, ed., Desertification: Environmental Degradation
Chapter 6

SOCIOLOGICAL ANALYSIS OF IRRIGATION WATER MANAGEMENT …. A PERSPECTIVE AND APPROACH TO ASSIST DECISION MAKING

David M. Freeman and Max K. Lowdermilk

The technical input required to improve water management is relatively simple. The problem is to formulate practical programs on a large scale which will allow for the technical, social, legal and political factors.... (World Bank, n.d.)

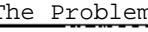

Irrigation water is of sociological interest because people must organize collectively to secure it, transport it, divide it into usable shares, enforce rules for its application, pay for it, and dispose of unused portions. The kinds of social organizations, the patterns of power, decision making, conflict, and cooperation which people create and maintain for the social control of water intimately affects the productivity of its use. Attempting to comprehend physical and agronomic problems of irrigation without probing into surrounding social organizational webs is like attempting to understand deficiencies in plant growth without reference to conditions of climate. When water moves efficiently from rivers, through a network of canals, to plant root zones, 'it is because people have effectively organized a decision system capable of enforcing technically sound rules for pursuing the collective interest. 